Journal of the Society for the Study of Architecture in Canada Le Journal de la Société pour l'étude de l'architecture au Canada

\title{
Introduction
}

\section{Malcolm Thurlby}

Volume 43, numéro 1, 2018

Religious Architecture in Canada

URI : https://id.erudit.org/iderudit/1049403ar

DOI : https://doi.org/10.7202/1049403ar

Aller au sommaire du numéro

Éditeur(s)

SSAC-SEAC

ISSN

2563-8696 (numérique)

Découvrir la revue

Citer ce document

Thurlby, M. (2018). Introduction. Journal of the Society for the Study of Architecture in Canada / Le Journal de la Société pour l'étude de l'architecture au Canada, 43(1), 3-5. https://doi.org/10.7202/1049403ar d'utilisation que vous pouvez consulter en ligne. 
B efore launching into my short overview of the papers in this volume, I wish to record formal thanks to Candace Iron and Jessica Mace, the organizers of the $43^{\text {rd }}$ Annual Conference of the Society for the Study of Architecture in Canada held at Niagara-on-the-Lake, May 24-27, 2017. Their administrative skills, tireless work before and during the conference, and, not least, their smiling faces and good humour, resulted in the best conference I have ever attended, and there have been a lot of them over the last forty-odd years, throughout North America and Europe.

The papers in this volume derive from the Religious Architecture sessions at two SSAC Annual Conferences, the $41^{\text {st }}$ at Annapolis Royal, May 27-30, 2015, and the $43^{\text {rd }}$ at Niagara-on-the-Lake, in 2017. Peter Coffman's essay, "Requiem for All Saints, Granville Centre," was presented at the Annapolis Royal meeting, while the remainder derive from presentations at Niagara-on-theLake. Of the other papers delivered at the $43^{\text {rd }}$ Conference, Paul Christianson, "'Correct Style': Recommendations on Church Architecture, Furnishings, and Worship in the Anglican Diocese of Toronto, 1849-1850," has already been published in the Journal of the Society for the Study of Architecture in Canada (vol. 42, no. 1, 2017, p. 79-108). Peter Coffman, "Filling the Empty Vessel: The Anglicans and the Inuit in Nineteenth-century Labrador," is forthcoming in Medieval Gothic Architecture and its Revivals: Transformation and Transmission through Time and Space, edited by Candice Bogdanski and Malcolm Thurlby (Newcastle upon Tyne, Cambridge Scholars Press, 2018). The present author gave a public lecture at the conference on historic churches in the Niagara Region-which will be developed for publication-one part of which was expanded to form an article titled "St. Andrew's Presbyterian Church, Niagaraon-the-Lake, and Church Design in Upper Canada down to 1840," for inclusion in this year's Georgian Group Journal (vol. 26, 2018, p. 116), so as to spread knowledge of Canadian architectural heritage outside national boundaries. The other presentations were: Luc Noppen, "A.W.N. Pugin's Influence on the Religious Architecture of Montréal's Catholic Diocese (1850-1875)"; Loryssa Quattrociocchi, "Gordon W. Lloyd (1832-1904): the Canadian Churches of Detroit's Architect"; Nicola Pezolet, "St. Ignatius of Loyola Parish at 100"; Jamie Scott, "Diaspora, Nostalgia, Invention: Sharif Senbel's British
Columbia Mosques"; and the present author's "'Correct' Fonts for Gothic Revival Churches in New Brunswick and Upper and Lower Canada"; are all being revised for publication. Add to these papers published in JSSAC from 2015 to 2017. Volume 40, no. 1, 2015: Candace Iron and Jean-Sebastien Sauvé, "Introduction," p. 34; Emily Turner, "Timber and Tin: Church Design and Construction in the James Bay Mission, 1850-1890," p. 514; Loryssa Quattrociocchi, "Two Churches by Gordon W. Lloyd (18321905): Trinity Anglican Church, St. Thomas, and New St. Paul's Anglican Church, Woodstock, and The Ecclesiological Gothic Revival in Southwestern Ontario," p. 1530; Malcolm Thurlby, "Bishop John Medley (1804-1892), Frank Wills (1822-1857), and the designs of Christ Church Cathedral and St. Anne's Chapel of Ease, Fredericton, New Brunswick, with some elementary remarks on the impact of Bishop John Medley and Frank Wills on the arrangements of Anglican churches in New Brunswick," p. 31-57; Luc Noppen, "French Architects in Early Twentieth-century French Canadian Church Architecture: the Contribution of Breton Architect Arthur Regnault in Nova Scotia (Acadia) and Québec City," p. 5973; and Maria-Dina Salvione, "Récit critique d'une sauvegarde réussie. L'église Christ Memorial Lutheran: Roger D'Astous et Jean-Paul Pothier (1964-1965)," p. 7582. Volume 41, no. 1, 2016: Emily Turner, "The Architecture of Sophistication in the Klondike Gold Rush: St. Paul's Anglican Church, Dawson, Yukon,"p. 4156. Volume 41, no. 2, 2016: Jean-Sébastien Sauvé, '“Il y a déjà assez et trop de gothique à Montréal.' Patrick C. Keely et la construction de l'église du Gesù de Montréal," p. 3550. Volume 42, no. 1, 2017: Malcolm Thurlby, "Christ's Church, Hamilton, Ontario, and The Changing Image of the Anglican Church - 1835-1875." Moreover, thirteen papers were presented in the Religious Architecture sessions at the Annual Conference in St. John's Newfoundland, May 2125, 2018. All of the above serve to indicate that the study of religious architecture in Canada is thriving, something that is very important in the quest to preserve our ecclesiastical built heritage.

Our papers are wide-ranging geographically, temporally, and methodologically. Buildings are from Nova Scotia, Quebec, Ontario, Saskatchewan, and Alberta. Dates are from 1814 to the early twentieth century for the buildings themselves, and, in terms of reuse, to the early twenty-first century. Anglican in Nova Scotia and Ontario, Roman Catholic in Quebec, Catholic and 
Presbyterian in Saskatchewan, and Mormonism in Alberta to reuse as Baptist in Louisiana.

In this issue of the JSSAC, Peter Coffman traces the history of the church of All Saints, Granville Centre (Nova Scotia), which was begun in 1814 under the patronage and influence of Charles Inglis, Bishop of Nova Scotia, 1787-1816, and the first colonial bishop in the history of the Church of England. For 194 years, it was a visual marker of Anglican and Loyalist identity in the Annapolis Valley. It manifested the architectural principles of the celebrated and influential Scottish architect James Gibbs [1682-1754]. In 2009 it was dismantled and subsequently re-assembled at 22380 Main Street, Abita Springs, Louisiana, as a Baptist church. Coffman's paper explores the amazing shift in identity that the building has undergone, and some of the complex questions raised by that transformation.

Winner of the Martin Eli Weil Prize, Alana Duggan, "The Churches of John G. Howard: The State of Research and Open Questions," presents the documentation for Howard churches and a meticulous analysis of his oeuvre of the 1830s and 1840s. The seemingly anomalous appearance of Holy Trinity, Chippawa, serves as an important reminder to always consider the demands of the building committee in the design of their church which has an application throughout the history of architecture.

Marc Grignon, "Charles Baillairgé's Interpretation of the Gothic Revival and the 'Cathedral' of Beauport, Quebec," is an exemplary interpretation of Baillairgé's 1849 Catholic parish church of La Nativité de Notre-Dame in Beauport, less than a year after Edward Staveley's Methodist temple of 1848-the first Gothic Revival church in Quebec City. The design is eclectic and follows neoclassical churches by Thomas Baillairgé and Charles himself, along with local Gothic adaptations based on James O'Donnell's Notre-Dame in Montreal and Staveley's Methodist temple. In addition, he references English and French cathedrals through his collection of architectural books, most particularly York Minster, knowledge of which may have come from Minard Lafever's Modern Builder's Guide of 1846. Grignon explores the meaning of such an eclectic attitude toward the Gothic at Beauport, an approach which may be extended to catholic churches in Ontario, such as William Thomas's 1845 St. Michael's Cathedral, Toronto. Baillairgé comments about the reconstruction of the church after it was destroyed by fire in 1890 are most instructive with regard to the improvement in the knowledge of Gothic detailing between 1850 and 1890. The ambitious appropriation of twin towers for the design of the façade from medieval Gothic cathedrals is not infrequent in Catholic Gothic church design in Canada, as in the Basilica of Our Lady, Guelph, ON, by Joseph Connolly (18761888), and St. Paul's Indian Catholic Church, North Vancouver, BC (1884-1909). Twin towers were eschewed by the Anglicans even though they were contemplated for Bishop John Medley's Anglican Cathedral, Fredericton, NB (1845), on the model of the transeptally placed towers at Exeter Cathedral. The final design used a cruciform plan with crossing tower which is also taken up at Christ Church Cathedral, Montreal, QC, commenced by Frank Wills in 1856. However, other denominations readily embraced the cathedral-like monumentality of the twintowered façade, for example: the Central Methodist Church in Woodstock, ON, by Langley, Langley and Burke (1875-1877); the Methodist Episcopal Church (now Lakeshore Drive United Church) (1880-1881) in Morrisburg, ON, by James P. Johnston of Ogdensburg, NY; and the Bekevar Presbyterian Reformed Church in Hazelwood, SK (unknown architect), discussed in Kristie's Dubé's paper in this issue.

Natalie Anderson Rathwell, "Heritage Value in Ottawa's Dominion-Chalmers United Church: History, Community, Sight, and Sound," examines the forces of faith, style, and practicality that resulted in this dynamic and historically wealthy congregation commissioning the 1912 Romanesque and Byzantine Revival gem that stands today. Drawing on the work of Jeanne Halgren Kilde, When Church Became Theater: The Transformation of Evangelical Architecture and Worship in Nineteenth-century America (Oxford, Oxford University Press, 2002), and Candace Iron, "Thomas John Rutley: A Presbyterian Church Designer" (JSSAC, vol. 30, no. 2, 2005, p. 3946), Rathwell investigates how the multisensory characteristics of this space function and were considered by the architect and building committee in relation to both the needs of the congregation and the architectural precedents from which Hutchison drew inspiration. Her approach to the multisensory properties of Hutchison's ecclesiastical designs has an application far beyond the confines of Dominion-Chalmers church, not least to the Baptist, Methodist, and Presbyterian churches of Langley and Burke and other architects working with amphitheatrical plans, and in the various churches by William Critchlow Harris in Prince Edward Island and Nova Scotia, which are renowned for their excellent acoustic qualities with wooden vaults.

Kristie Dubé, "Minority Immigrant Narratives in Saskatchewan: Kaposvar Roman Catholic Church and Bekevar Presbyterian/ Reformed Church," investigates these two churches in light of the diversity of the pioneer period of the early twentieth 
century in Saskatchewan. Rather than focus on the denominational differences, Dubé maintains that Bekevar Presbyterian (1911) and Kaposvar Roman Catholic (1906-1907) churches altered the language of church architecture in ways to reflect their own aspirations, which brought alternative voices into Canada's built landscape.

Brooke Kathleen Brassard, "Vines, Gates, and Temples: Using Cemeteries to Understand Mormonism in Canada," investigates Mormon towns in southern Alberta, first settled in 1887, with a focus on cemeteries, gravestones, and architecture as expressions of identity. The approach may be compared with Jennifer McKendry's Into the Silent Land: Historic Cemeteries and Graveyards in Ontario (Kingston, self-published, 2003). Brassard examines data from six cemeteries. During the Mormons first decade in Canada, there was nothing specifically "Mormon" about their graves. In the 1900s, they favoured Mormon symbols related to their views of afterlife. Finally, with the construction of the Cardston Temple in the 1910s, the Mormons in Alberta solidified their presence in the nation and images of the sacred structure in their cemeteries marked their confidence as Canadians.

\section{NOTES}

1. Thurlby, Malcolm, 2016, "The Roman Catholic Churches of Joseph Connolly (18401904): The Adaptation of Pugin's True Principles and Aspects of Irish Identity in Ontario," in Timothy Brittain-Catlin, Jan De Maeyer, and Martin Bressani (eds.), Gothic Revival Worldwide: A.W.N. Pugin's Global Influence, Leuven, Leuven University Press, p. 7693.

2. Epstein, Clarence, 2012, Montreal, City of Spires: Church Architecture during the British Colonial Period 1760-1860, Québec, Presses de I'Université du Québec, p. 193195. 